\title{
A Case of Thyrotoxicosis-induced Anemia After the Onset of Painless Thyroiditis in a Patient With Pancreatic Diabetes Mellitus: Profile of Hemoglobin, Thyroid Hormones, Soluble IL-2 Receptor, LDL-C, HDL-C and Liver Function.
}

Ichiro Komiya ( $\square$ i.kom.iya@nifty.com )

Okinawa Medical Hospital https://orcid.org/0000-0002-4965-4561

Noriharu Yagi

Yagi Internal Medicine Clinic

Takeaki Tomoyose

Okinawa Red Cross Hospital

Gen Ouchi

University of Ryukyus Hospital

Tamio Wakugami

Okinawa Medical Hospital

\section{Case report}

Keywords: painless thyroiditis, normocytic anemia, silL-2R, cholesterol, liver function

Posted Date: December 23rd, 2020

DOI: https://doi.org/10.21203/rs.3.rs-129765/v1

License: (-) (1) This work is licensed under a Creative Commons Attribution 4.0 International License. Read Full License

Version of Record: A version of this preprint was published at Thyroid Research on April 23rd, 2021. See the published version at https://doi.org/10.1186/s13044-021-00100-6. 


\section{Abstract}

Background: There have been several reports of secondary anemia associated with Graves' disease. There are no reports of secondary anemia resulting from thyrotoxicosis due to painless thyroiditis (silent thyroiditis). We report the case of a patient with pancreatic diabetes who developed normocytic anemia caused by thyrotoxicosis due to painless thyroiditis.

Case presentation: The patient was a 37-year-old man who visited the hospital complaining of fatigue, palpitations, and dyspnea. His hemoglobin was $110 \mathrm{~g} / \mathrm{l}$, and mean corpuscular volume was $81.5 \mathrm{fl}$. His free thyroxine (FT4) was high, at $1.004 \mathrm{pmol} / \mathrm{l}$, the free triiodothyronine (FT3) was high, at $27.49 \mathrm{pmol} / \mathrm{l}, \mathrm{TSH}$ was $<0.01 \mathrm{mIU} / \mathrm{I}$, and TSH receptor antibody was negative. Soluble IL-2 receptor (sIL-2R) was high, at 1,340 U/ml, low-density lipoprotein cholesterol (LDL-C) was $0.78 \mathrm{mmol} / \mathrm{l}$, and high-density lipoprotein cholesterol (HDL-C) was $0.75 \mathrm{mmol} / \mathrm{l}$. Propranolol was prescribed and followed up. Thyroid hormones, sIL-2R, LDL-C, and HDL-C had almost normalized by 8 weeks after onset. Anemia completely disappeared by 12 weeks after disease onset. Slight increases in liver enzyme levels and a decrease in serum albumin were observed, and recovered later than normalization of thyroid function and cholesterol levels. He developed mild hypothyroidism and was treated with L-thyroxine at 24 weeks.

Conclusions: This is the first case report of transient secondary anemia associated with thyrotoxicosis due to painless thyroiditis. Changes in SIL-2R, HDL-C, LDL-C and liver function were also observed during the clinical course of thyrotoxicosis and anemia, suggesting the autoimmune processes in thyroid gland, bone marrow and liver.

\section{Background}

Secondary anemia associated with hyperthyroidism is a relatively rare complication [1]. Many reports have shown that although anemia progresses with hyperthyroidism in Graves' disease, it is often transient, improving with treatment of Graves' disease [2,3]. There are no reports of secondary anemia resulting from thyrotoxicosis due to subacute thyroiditis, painless thyroiditis (silent thyroiditis) [4], or other causes. Here, we report a case of transient normocytic anemia that developed after the onset of painless thyroiditis in a patient with pancreatic diabetes treated with insulin.

\section{Case Presentation}

A 37-year-old man visited our hospital due to gradually progressive fatigue, dyspnea, and palpitations of approximately 14 days duration. His pulse was 104 beats/min, and his body temperature was $36.8^{\circ} \mathrm{C}$. No increase in sweating was observed, goiter was not palpable, and no exophthalmos or ocular movement dysfunction was observed. Laboratory examination showed normocytic anemia ( $\mathrm{Hgb} 110 \mathrm{~g} / \mathrm{l}$, mean corpuscular volume [MCV] $81.5 \mathrm{fl})$, and serum iron and ferritin were within the normal ranges. Reticulocytes were increased at the time of onset. The FT4 (free thyroxine) level was high, at $1.004 \mathrm{pmol} / \mathrm{l}$, the FT3 (free triiodothyronine) level was high, at $27.49 \mathrm{pmol} / \mathrm{l}$, and his TSH was $<0.01 \mathrm{mlU} / \mathrm{l}$. TSH receptor antibody, anti-TPO antibody or anti-thyroglobulin antibody were negative. In other clinical tests, soluble interleukin-2 receptor (sIL-2R), measured for differentiation of hematologic malignancies, was high, at $1,340 \mathrm{U} / \mathrm{ml}$; his low-density lipoprotein cholesterol (LDL-C) was low, at $0.78 \mathrm{mmol} / \mathrm{l}$, and his high- density lipoprotein cholesterol (HDL-C) was low, at $0.75 \mathrm{mmol} / \mathrm{l}$ (Table 1$)$. 
Table 1

Profile of laboratory data for a diabetes patient with thyrotoxicosis due to painless thyroiditis

\begin{tabular}{|c|c|c|c|c|c|c|c|c|c|c|c|}
\hline Variables & $\begin{array}{l}\text { Standard } \\
\text { range }\end{array}$ & $\begin{array}{l}\text { Day } \\
-56\end{array}$ & $\begin{array}{l}\text { Day } \\
-28\end{array}$ & $\begin{array}{l}\text { Day } \\
0\end{array}$ & Day 14 & Day 28 & $\begin{array}{l}\text { Day } \\
56\end{array}$ & $\begin{array}{l}\text { Day } \\
84\end{array}$ & $\begin{array}{l}\text { Day } \\
112\end{array}$ & $\begin{array}{l}\text { Day } \\
140\end{array}$ & $\begin{array}{l}\text { Day } \\
168\end{array}$ \\
\hline $\begin{array}{l}\text { Red blood cells } \\
\text { (RBC), } 10^{12} / \mathrm{I}\end{array}$ & $\begin{array}{l}4.27- \\
5.70\end{array}$ & 4.80 & 4.96 & 3.78 & 3.77 & 3.84 & 4.50 & 4.77 & 4.93 & 4.88 & 4.66 \\
\hline $\begin{array}{l}\text { Hemoglobin } \\
(\mathrm{Hgb}), \mathrm{g} / \mathrm{l}\end{array}$ & $135-176$ & 144 & 146 & 110 & 107 & 109 & 126 & 136 & 142 & 146 & 140 \\
\hline $\begin{array}{l}\text { Hematocrit } \\
\text { (Hct), /I }\end{array}$ & $\begin{array}{l}0.398- \\
0.518\end{array}$ & 0.399 & 0.408 & 0.308 & 0.305 & 0.306 & 0.352 & 0.377 & 0.392 & 0.396 & 0.408 \\
\hline $\begin{array}{l}\text { Mean } \\
\text { corpuscular } \\
\text { volume (MCV), } \\
\text { fl }\end{array}$ & $\begin{array}{l}81.7- \\
101.6\end{array}$ & 83.1 & 82.3 & 81.5 & 80.9 & 79.7 & 78.2 & 79.0 & 79.5 & 82.8 & 83.4 \\
\hline $\begin{array}{l}\text { White blood } \\
\text { cells (WBC), } 10^{9} \\
\text { /I }\end{array}$ & $3.5-9.8$ & 6.4 & 7.4 & 5.3 & 7.2 & 6.5 & 8.8 & 8.6 & 8.8 & 5.8 & 7.4 \\
\hline Platelets, $10^{9} / \mathrm{I}$ & $130-369$ & 272 & 315 & 254 & 198 & 228 & 289 & 266 & 283 & 322 & 333 \\
\hline $\begin{array}{l}\text { Reticulocytes, } \\
10^{9} / \text { I }\end{array}$ & $30-100$ & & & 108 & 68 & & & & & & \\
\hline $\begin{array}{l}\text { Thyroid } \\
\text { stimulating } \\
\text { hormone (TSH), } \\
\text { mIU/I }\end{array}$ & $\begin{array}{l}0.50- \\
5.00\end{array}$ & & & $\hat{0} 01$ & $<0.01$ & $<0.01$ & $\dot{0} 01$ & & 10.1 & 15.2 & 18.5 \\
\hline $\begin{array}{l}\text { Free } \\
\text { triiodothyronine } \\
\text { (FT3), pmol/I }\end{array}$ & $\begin{array}{l}3.53- \\
6.14\end{array}$ & & & & 27.49 & 12.61 & 9.37 & & 3.93 & 4.35 & 4.22 \\
\hline $\begin{array}{l}\text { Free thyroxine } \\
\text { (FT4), pmol/l }\end{array}$ & $\begin{array}{l}0.116- \\
0.219\end{array}$ & & & 1.004 & 0.914 & 0.515 & 0.331 & & 0.140 & 0.131 & 0.140 \\
\hline $\begin{array}{l}\text { TSH receptor } \\
\text { antibody } \\
\text { (TRAb), mIU/I }\end{array}$ & $<2.0$ & & & & 0.4 & & & & & & \\
\hline $\begin{array}{l}\text { Anti-TPO } \\
\text { antibody, IU/ml }\end{array}$ & $<16$ & & & & 9 & & & & & & \\
\hline $\begin{array}{l}\text { Ant- } \\
\text { thyroglobulin } \\
\text { antibody, IU/ml }\end{array}$ & $<28$ & & & & 11 & & & & & & \\
\hline $\begin{array}{l}\text { C-reactive } \\
\text { protein (CRP), } \\
\mu \mathrm{g} / \mathrm{l}\end{array}$ & $<3,000$ & & & 6,900 & & 12,100 & 5,700 & 3,700 & & 1,200 & \\
\hline $\mathrm{Fe}, \mu \mathrm{mol} / \mathrm{l}$ & $9.1-35.5$ & & & 9.5 & & 9.5 & & & & & \\
\hline $\mathrm{TIBC}, \mu \mathrm{mol} / \mathrm{I}$ & $\begin{array}{l}43.2- \\
69.0\end{array}$ & & & 34.2 & & 40.8 & & & & & \\
\hline Ferritin, $\mu \mathrm{g} / \mathrm{l}$ & $13-401$ & & & 389 & & 376 & 396 & & & & \\
\hline $\begin{array}{l}\text { Soluble IL-2 } \\
\text { receptor (sIL- } \\
2 \mathrm{R}), \mathrm{U} / \mathrm{ml}\end{array}$ & $122-496$ & & & 1,340 & & 1,010 & 808 & & 472 & & 365 \\
\hline HDL-C, mmol// & $\begin{array}{l}1.03- \\
2.48\end{array}$ & 1.27 & 1.09 & 0.75 & & 0.98 & 1.27 & 1.42 & 1.14 & 1.16 & 1.14 \\
\hline LDL-C, mmol// & $\begin{array}{l}1.68- \\
3.59\end{array}$ & 1.99 & 1.63 & 0.78 & & 1.45 & 2.12 & 2.82 & 2.87 & 2.90 & 2.82 \\
\hline
\end{tabular}

eGFR, estimated glomerular filtration rate. Bold data is abnormal value. 


\begin{tabular}{|c|c|c|c|c|c|c|c|c|c|c|c|}
\hline Variables & $\begin{array}{l}\text { Standard } \\
\text { range }\end{array}$ & $\begin{array}{l}\text { Day } \\
-56\end{array}$ & $\begin{array}{l}\text { Day } \\
-28\end{array}$ & $\begin{array}{l}\text { Day } \\
0\end{array}$ & Day 14 & Day 28 & $\begin{array}{l}\text { Day } \\
56\end{array}$ & $\begin{array}{l}\text { Day } \\
84\end{array}$ & $\begin{array}{l}\text { Day } \\
112\end{array}$ & $\begin{array}{l}\text { Day } \\
140\end{array}$ & $\begin{array}{l}\text { Day } \\
168\end{array}$ \\
\hline $\begin{array}{l}\text { Triglycerides } \\
(\mathrm{TG}), \mathrm{mmol} / \mathrm{l}\end{array}$ & $\begin{array}{l}0.34- \\
1.68\end{array}$ & 0.46 & 0.59 & 0.54 & & 0.84 & 0.68 & 0.75 & 0.84 & 0.59 & 0.60 \\
\hline $\begin{array}{l}\mathrm{HbA} \text { Hc } \\
\%\end{array}$ & $4.6-6.2$ & 6.9 & 7.1 & 7.6 & & 6.5 & 6.6 & 6.9 & 7.7 & 7.6 & 7.5 \\
\hline AST, IU/I & $13-33$ & 19 & 18 & 21 & & 25 & 30 & 25 & 22 & 27 & 23 \\
\hline ALT, IU/I & $6-30$ & 13 & 14 & 19 & & 28 & 29 & 21 & 15 & 22 & 21 \\
\hline YGTP, IU/I & $10-47$ & 13 & 14 & 21 & & 42 & 57 & 37 & 26 & 20 & 19 \\
\hline Albumin, g/l & $40-50$ & 41 & 42 & 31 & & 32 & 36 & 36 & 35 & 41 & 41 \\
\hline $\begin{array}{l}\text { eGFR, } \\
\mathrm{ml} / \mathrm{min} / 1.73 \mathrm{~m}^{2}\end{array}$ & $>60$ & 103 & 97 & 111 & & 115 & 104 & 90 & 88 & 79.0 & 80.0 \\
\hline \multirow[t]{2}{*}{ Drug treatment } & & & & & Propranolol & Propranolol & & & & & LT4 \\
\hline & & & & & $30 \mathrm{mg}$ & $30 \mathrm{mg}$ & & & & & $\begin{array}{l}12.5 \\
\mu \mathrm{g}\end{array}$ \\
\hline
\end{tabular}

The patient was previously diagnosed with pancreatic diabetes due to alcoholic pancreatitis at age 25 years, and thus, he was treated with a combination of insulin glargine and insulin aspart. Regular clinical examinations were performed every 28 days, and no abnormalities were found in his biochemical data or complete blood count, other than his plasma glucose and HbA1c. Propranolol ( $30 \mathrm{mg} /$ day) was prescribed at day 14 and stopped on day 56 . Thyroid ultrasonography was performed on day 28 , and hypoechoic regions were observed throughout the thyroid gland (Fig. 1).

The patient's thyroid hormone levels had almost normalized by day 56, and his LDL-C and HDL-C normalized by day 56 (Fig. $2 A$ ). The anemia disappeared by day 84 , and sIL-2R normalized by day 112 . There were slight increases in liver enzymes at disease onset, but these increases disappeared by day 140 (Fig. 2B). However, the time to normalization was several weeks behind that of thyroid hormone, LDL-C, and HDL-C normalization. His serum albumin was low at onset but normalized by day 140 . The patient's insulin regimen was not changed over the entire clinical course. He developed mild hypothyroidism on day 112 and was started on $12.5 \mu \mathrm{g}$ of L-thyroxine replacement therapy on day 168 (Table 1).

\section{Discussion And Conclusions}

We reported a case of thyroiditis-induced thyrotoxicosis that suddenly led to normocytic anemia within 4 weeks after the patient's last visit to our hospital. The patient's TSH receptor antibody was negative, his FT3/FT4 ratio was low[5], and the destructive findings on thyroid ultrasonography indicated painless thyroiditis. This is the first report of secondary anemia associated with painless thyroiditis. Although the levels remained within the normal range, mild leukopenia and thrombocytopenia presented at disease onset, suggesting pancytopenia due to thyrotoxicosis ${ }^{3}$. Pancytopenia completely disappeared by 12 weeks after onset, with spontaneous remission of thyrotoxicosis.

Painless thyroiditis (silent thyroiditis) is a self-limiting inflammatory disorder of the thyroid gland characterized by an early thyrotoxicosis phase caused by the release of thyroid hormones and a late hypothyroidism phase, with complete resolution in most cases $[4,6]$. The pathophysiologic mechanism of painless thyroiditis is unknown, but the possibility of immune disorder involvement has been suggested [6, 7]. Painless thyroiditis generally manifests as a lymphocyte infiltration of the thyroid follicles, causing thyroid follicular cell damage. In our case, we observed a typical course of painless thyroiditis. The secondary anemia caused by thyrotoxicosis has improved, but we would like to carefully follow up on the continuation of thyroid hormone replacement therapy.

The mechanism by which anemia develops in thyrotoxicosis is not clear. Shortened erythrocyte survival or ineffective erythropoiesis have been suggested as potential causes of anemia in thyrotoxicosis [2, 3]. Moreover, mild leukopenia and thrombocytopenia were observed in our case, which could have been due to a variety of mechanisms. The involvement of autoantibodies in leukocytes and 
platelets has been reported [8]. The involvement of immune processes in the onset of painless thyroiditis could help explain the pathophysiology of pancytopenia [9]. The patient had an history of acute pancreatitis. It is interesting to assume the immune mechanisms as the pathogenesis of acute and chronic pancreatitis [10].

In addition to the clinical course of thyrotoxicosis and associated anemia, the present case provided interesting laboratory data. First, SIL-2R was high at onset but normalized by 16 weeks after onset of anemia. Elevated levels of sIL-2R have been reported in hyperthyroidism of Graves' disease [11] and thyrotoxicosis due to painless thyroiditis [12], and it is known that thyroid hormones directly enhance sIL-2R production in lymphocytes [12]. Second, LDL-C and HDL-C levels decreased due to thyrotoxicosis but then normalized. Excessive thyroid hormone levels lower serum LDL-C levels via LDL receptor [13] and PCSK9 [14] and lower HDL-C levels via increased CETP activity [15]. In addition, we previously reported that increased SIL-2R cause significant decreases levels in HDL-C and LDL-C in patients with hematologic malignancies [16]. Increased cytokines were recently reported to be associated with hypolipidemia in COVID-19 patients [17]. Presumably, increases in levels of both thyroid hormones and sIL-2R induce the decreases in HDL-C and LDL-C. In addition, slight decreases in HDL-C and LDL-C levels were observed 4 weeks before onset, which may have preceded the anemia. Third, slight increases in liver enzyme levels and a decrease in serum albumin were observed, but these changes disappeared with normalization of thyroid function. However, the time to disappearance was several weeks behind the normalization of $\mathrm{Hgb}, \mathrm{LDL}-\mathrm{C}$, and HDL-C. The reason for this is unknown. The duration of propranolol administration and the deterioration of liver function did not match. These data suggest that autoimmune processes in the liver could be associated with the different time courses in the normalization of cholesterol and hepatic enzyme levels [9].

In conclusion, we reported the case of a diabetes patient with secondary anemia resulting from thyrotoxicosis. Thyrotoxicosis was caused by painless thyroiditis, but there have been no reports of secondary anemia induced by painless thyroiditis. Changes in SIL-2R, HDL-C, LDL-C and liver function were also observed during the clinical course of thyrotoxicosis and anemia.

\section{List Of Abbreviations}

TSH, thyroid stimulating hormone; FT4, free thyroxine; FT3, free triiodothyronine; sIL-2R, soluble interleukin-2 receptor; HDL-C, highdensity lipoprotein cholesterol; LDL-C, low-density lipoprotein cholesterol.

\section{Declarations}

\section{Ethics approval and consent to participate}

No applicable.

\section{Consent for publication}

Regarding publication of the case report, we explained that we could not reveal personal information and obtained verbal consent from the patient.

\section{Availability of data and materials}

The collection of data that supports the findings in this study is available from Okinawa Medical Hospital. Data are available from the authors upon reasonable request and with permission of Okinawa Medical Hospital.

\section{Competing interests}

The authors declare no conflict of interest.

\section{Funding Information}

The authors received no specific funding for this work.

\section{Author Contributions}

TW has full access to all of the data from the study and takes responsibility for the integrity of the data. IK and TT were involved in study design, interpreting data, statistical analysis, creating tables and figures, and drafting the manuscript. NY and GO were involved in 
interpreting data and supervised the work. All authors have contributed significantly to this work. All the authors have read the manuscript and have approved this submission.

\section{Acknowledgements}

We would also like to thank FORTE (www.forte-science.co.jp) for English language editing.

\section{References}

1. Ford HC, Carter JM. The haematology of hyperthyroidism: abnormalities of erythrocytes, leucocytes, thrombocytes and haemostasis. Postgrad Med J. 1998;64:735-42.

2. Szczepanek-Parulska E, Hernik A, Ruchała M. Anemia in thyroid diseases. Pol Arch Intern Med. 2017;127:352-60.

3. Garla VV, Salim SA, Yanes-Cardozo LL. Pancytopenia: a rare complication of Graves' disease. BMJ Case Rep. 2018: bcr2017223887.

4. Mizukami Y, Michigishi T, Hashimoto T, Tonami N, Hisada K, Matsubara F, et al. . Silent thyroiditis: a histologic and immunohistochemical study. Hum Pathol. 1988;19:423-31.

5. Yoshimura JN, Momotani N, Fukada S, Ito K, Miyauchi A, Amino N. Ratio of serum free triiodothyronine to free thyroxine in Graves' hyperthyroidism and thyrotoxicosis caused by painless thyroiditis. Endocr J. 2005;52:537-42.

6. Strakosch CR. Thyroiditis. Aust N Z J Med. 1986;16:91-100.

7. Takasu N, Komiya I, Nagasawa Y, Asawa T, Yamada T. Exacerbation of autoimmune thyroid dysfunction after unilateral adrenalectomy in patients with Cushing's syndrome due to an adrenocortical adenoma. N Engl J Med. 1990; 322:1708-12.

8. Lima CSP, Zantut Wittmann DE, Castro V, Tambascia MA, Lorand-Metze I, Saad STO, et al. Pancytopenia in untreated patients with Graves' disease. Thyroid. 2006:16:403-409.

9. Nobili V, Liaskos C, Luigi G, Guidi R, Francalanci P, Marcellini M. Autoimmune thyroiditis associated with autoimmune hepatitis. Thyroid. 2005: 15:1193-5.

10. Lee B, Zhao Q, Habtezion A. Immunology of pancreatitis and environmental factors. Curr Opin Gastroenterol. 2017;33:383-9.

11. Koukkou E, Panayiotidis P, Alevizou-Terzaki V, Thalassinos N. High levels of serum soluble interleukin-2 receptors in hyperthyroid patients: correlation with serum thyroid hormones and independence from the etiology of the hyperthyroidism. J Clin Endocrinol Metab. 1991;73:771-6.

12. Hamamoto $\mathrm{K}$, Inaba M, Yamada S, Yoda M, Yoda K, Goto H, et al. Increased soluble IL-2 receptor levels in serum from a patient with painless thyroiditis. Thyroid Res. 2013;6:12.

13. Lopez D, Socarrás JFA, Bedi M, Ness GC. Activation of the hepatic LDL receptor promoter by thyroid hormone. Biochim Biophys Acta. 2007;1771:1216-25.

14. Bonde Y, Breuer O, Lütjohann D, Sjöberg S, Angelin B, Rudling M. Thyroid hormone reduces PCSK9 and stimulates bile acid synthesis in humans. J Lipid Res. 2014;55:2408-15.

15. Tan KC, Shiu SW, Kung AW. Plasma cholesteryl ester transfer protein activity in hyper- and hypothyroidism. J Clin Endocrinol Metab. 1998;83:140-3.

16. Komiya I, Tomoyose T, Ouchi G, Yara T, Higa S. Low level of serum HDL-cholesterol with increased sIL-2R predicts a poor clinical outcome for patients with malignant lymphoma and adult T-cell leukemia-lymphoma. Cytokine. 2018;105:57-62.

17. Wei X, Zeng W, Su J, Wan H, Yu X, Cao X, et al. Hypolipidemia is associated with the severity of COVID-19. J Clin Lipidol. 2020;14:297-304.

\section{Figures}




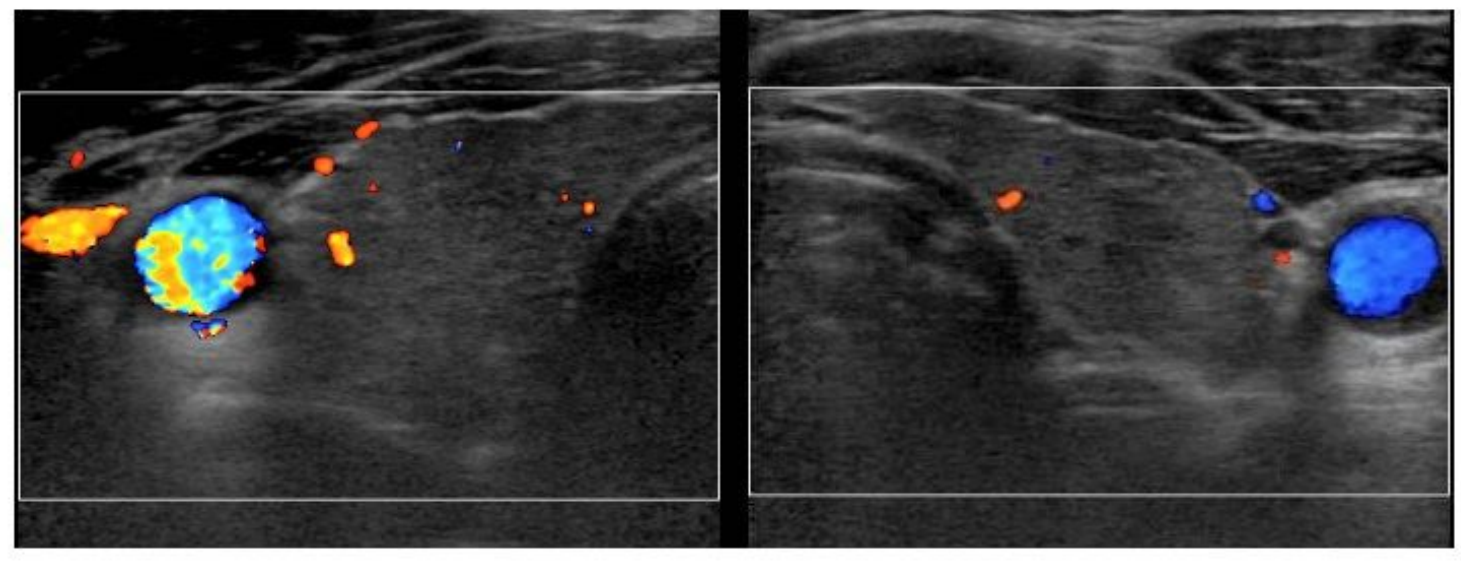

\section{Figure 1}

Thyroid ultrasonography findings. Hypoechoic regions are scattered throughout the thyroid gland. No increase in blood flow in the thyroid gland was observed.

Fig. 2A

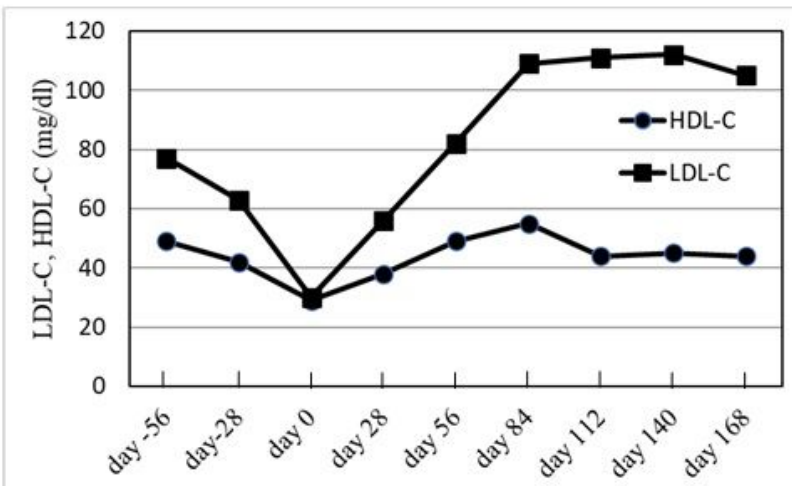

Fig. 2B

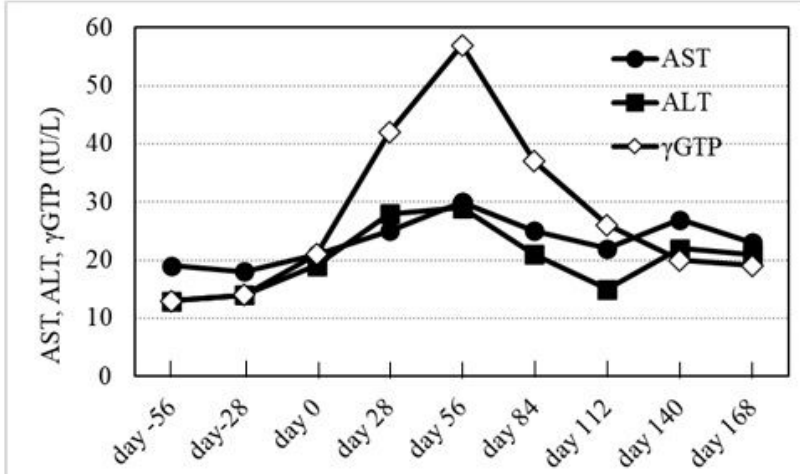

Figure 2

Profile of LDL-C and HDL-C levels and changes in liver function tests. There were slight decreases in LDL-C and HDL-C levels 28 days before onset, and levels were lowest at the time of onset. Both returned to their previous values by day 56 (Fig. 2A). Serum albumin reached its lowest level at onset but recovered by day 140. Liver enzyme levels exhibited a slight increase after the improvement of anemia and thyroid function. The liver enzyme increase continued to day 112 (Fig. 2B). 